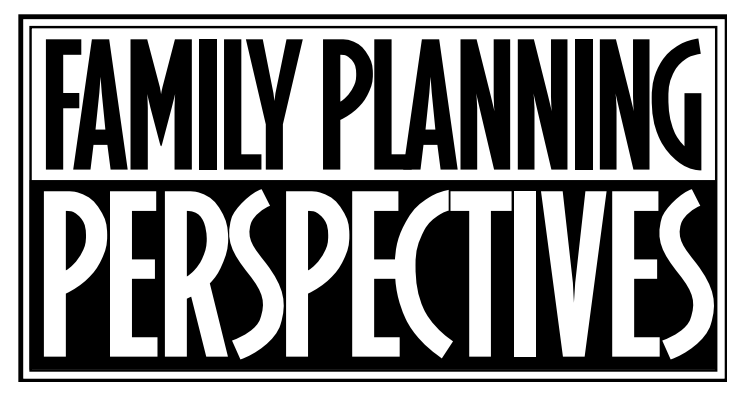

\title{
Reader Survey
}

We value your opinion and advice on our journal. Please take a few minutes to answer the following questions and return the survey to us. Your answers will help us evaluate the journal and improve the information that it provides to you.

1. Which category best describes the organization you work for?

$\begin{array}{lc}\square \text { Academic institution } & \square \text { Media/communications } \\ \square \text { Research organization } & \square \text { Advocacy group } \\ \square \text { Hospital } & \square \text { Federal/state/local } \\ \square \text { Health clinic } & \text { government } \\ \square \text { Planned Parenthood } & \square \text { Foundation } \\ \square \text { Other (please specify) } & \end{array}$

2. Which category best describes your work in the organization or your interest in the reproductive health field?

$\begin{array}{lc}\square \text { Research } & \square \text { Policy analysis } \\ \square \text { Service delivery } & \square \text { Media/communications } \\ \square \text { Education/training } & \square \text { Project support } \\ \square \text { Policy-making } & \text { (funding) } \\ \square \text { Advocacy } & \square \text { Administration/ } \\ & \text { management } \\ \square \text { Other (please specify) } & \end{array}$

3. Which category best describes your area of expertise?

$\begin{array}{ll}\square \text { Demography } & \square \text { Psychology } \\ \square \text { Economics } & \square \text { Public health } \\ \square \text { Obstetrics/gynecology } & \square \text { Sociology/anthropology } \\ \square \text { Pediatrics } & \square \text { Women's health/rights } \\ \square \text { Public policy } & \square \text { Education } \\ \square \text { Epidemiology } & \square \text { Health care services } \\ \square \text { Other (please specify) } & \end{array}$

4. Family Planning Perspectives regularly publishes material on the following topics. Which of these are of most interest to you? Check all that apply.

$\begin{array}{ll}\square \text { Abortion } & \square \text { Program operation/ } \\ \square \text { Adolescent pregnancy } & \text { evaluation } \\ \square \text { Contraceptive use } & \square \text { Public policy } \\ \square \text { Fertility behavior/ } & \square \text { Sexual behavior } \\ \text { trends } & \square \text { Sexuality education }\end{array}$

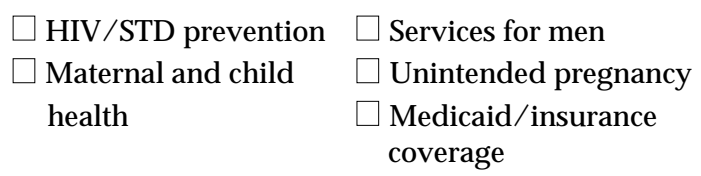

Other, less frequent topics (please specify)

5. If Family Planning Perspectives broadened its coverage, what new topics do you think should be included?

$\square$ Needs of prospective and new parents

$\square$ New reproductive technologies

$\square$ Sexual/domestic violence

Understanding sexuality

$\square$ The roles of men

$\square$ Services for pre/postmenopausal women

$\square$ Gender equity

Other (please specify)

6. How important is Family Planning Perspectives to your work?

$\square$ Very important $\quad \square$ Not at all important
$\square$ Somewhat important

7. Which 3-4 journals other than Family Planning Perspectives do you consider essential reading for your work?

8. What section of Family Planning Perspectives is most useful to you?

$\begin{array}{ll}\square \text { Update } & \square \text { Comments } \\ \square \text { Articles } & \square \text { Viewpoints } \\ \square \text { Special Report } & \square \text { Forums } \\ \square \text { Digests } & \end{array}$


9. When you receive the journal, what do you typically read?

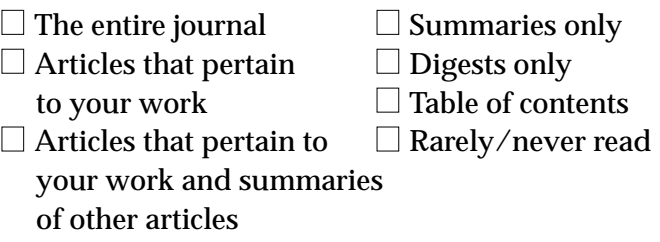

10. After you read your copy of the journal, do you

$\square$ File it for future reference $\square$ Give it to a library

$\square$ Pass it on to someone else $\square$ Throw it away

11. Can you estimate how many other people read your copy of the journal?

$\begin{array}{ll}\square \text { None } & \square \text { Four to six } \\ \square \text { One to three } & \square \text { Seven or more }\end{array}$

12. Which of the following features would you like to see in the journal?

$\begin{array}{lc}\square \text { Annotated list of } & \square \text { Columns by leaders } \\ \text { new books } & \text { in the field } \\ \square \text { Annotated list of } & \square \text { Q\&As with leaders in } \\ \text { relevant Web sites } & \text { the field } \\ \square \text { Notice of upcoming } & \square \text { Excerpts from legis- } \\ \text { meetings } & \text { lation, policy papers } \\ \square \text { Opinion and analysis } & \text { and court decisions } \\ \square \text { Other (please specify) } & \end{array}$

13. Would you be interested in an electronic subscription to the journal?

$\square$ Yes $\square$ No

14. What do you consider the journal's greatest strengths?

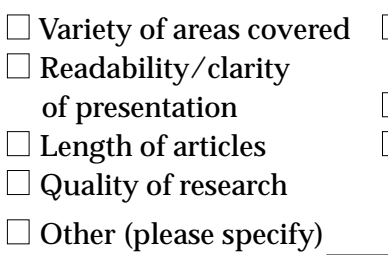

$$
\begin{aligned}
& \square \text { Digests of research } \\
& \text { published elsewhere } \\
& \square \text { Design } \\
& \square \text { Article Summaries }
\end{aligned}
$$

15. What do you consider the journal's major weaknesses?

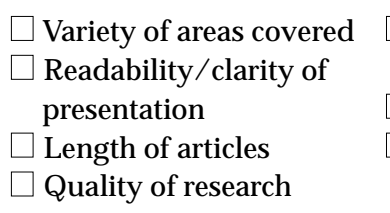

Other (please specify)
17. Would you be willing to participate in a more indepth discussion of the journal? If so, please provide your name, phone number and e-mail address.

Name:

Telephone No.:

E-mail address:

\section{Thank you}

\section{BUSINESS REPLY MAIL}

FIRST CLASS MAIL PERMIT NO. 1975 NEW YORK, NY

POSTAGE WILL BE PAID BY ADDRESSEE

THE ALAN GUTTMACHER INSTITUTE

120 WALL STREET

NEW YORK NY 10269-0584 